\title{
Decline of Prairie Dog Towns in Southwestern North Dakota
}

\author{
NORMAN G. BISHOP AND JAMES L. CULBERTSON
}

Highlight: Aerial photographs for 1939 to 1972 were examined to evaluate the impact of rodent control programs and land use practices on prairie dog towns on a portion of the Little Missouri National Grasslands. Colonies were measured for three periods during the 33-year span and showed an $89 \%$ decline in number and a 93\% decline in acreage. A verage town size was not significantly affected during the decline and was not significantly different on federal land compared to private or state land. Colonies were largely eliminated on the best agricultural bottom lands but appeared to be more persistent near the undisturbed colonies in Theodore Roosevelt National Memorial Park. Reported sightings indicate that some black-footed ferrets have probably survived in the area. The new perspective has resulted in improved management for the two species.

Federal legislation protecting endangered species has resulted in increasing interest in the welfare of the black-tailed prairie dog (Cynomys ludovicianus) (Fig. 1). Prairie dog towns (Fig. 2) provide habitat for the endangered black-footed ferret (Mustela nigripes) and a close relationship exists between the species as reported by Henderson et al. (1969), Sheets (1970), and Hillman and Linder (1973). The Endangered Species Acts approved in 1969 and 1973 provided protection for the black-footed ferret and incentives for government conservation agencies to initiate endangered species habitat survey and management programs. The new laws require re-evaluation of the impacts of range management programs on endangered species habitat, especially on public lands.

Surveys of the recent distribution and status of prairie dogs and blackfooted ferrets have been conducted by state and federal conservation agencies over most of their range. Within the former range of the prairie $\operatorname{dog}$ and ferret from Texas to Saskatchewan, prairie dog towns have generally been reduced in size and number largely by agricultural practices and poisoning (Cheatheam, 1973; Lewis and Hassien, 1973; Henderson and Little, 1973; Lock, 1973; Rose, 1973; Grondahl, 1973; Scheelhaase, 1973). Few, if any, of these surveys have measured the

Authors are supervisory forestry technician, Custer National Forest, Medora Ranger District, Dickinson, North Dakota; and wildlife biologist, Custer National Forest, Dakotas Planning Team, Dickinson, North Dakota.

Manuscript received April 14, 1975. fluctuations in prairie dog towns for a large area over a long period of time.

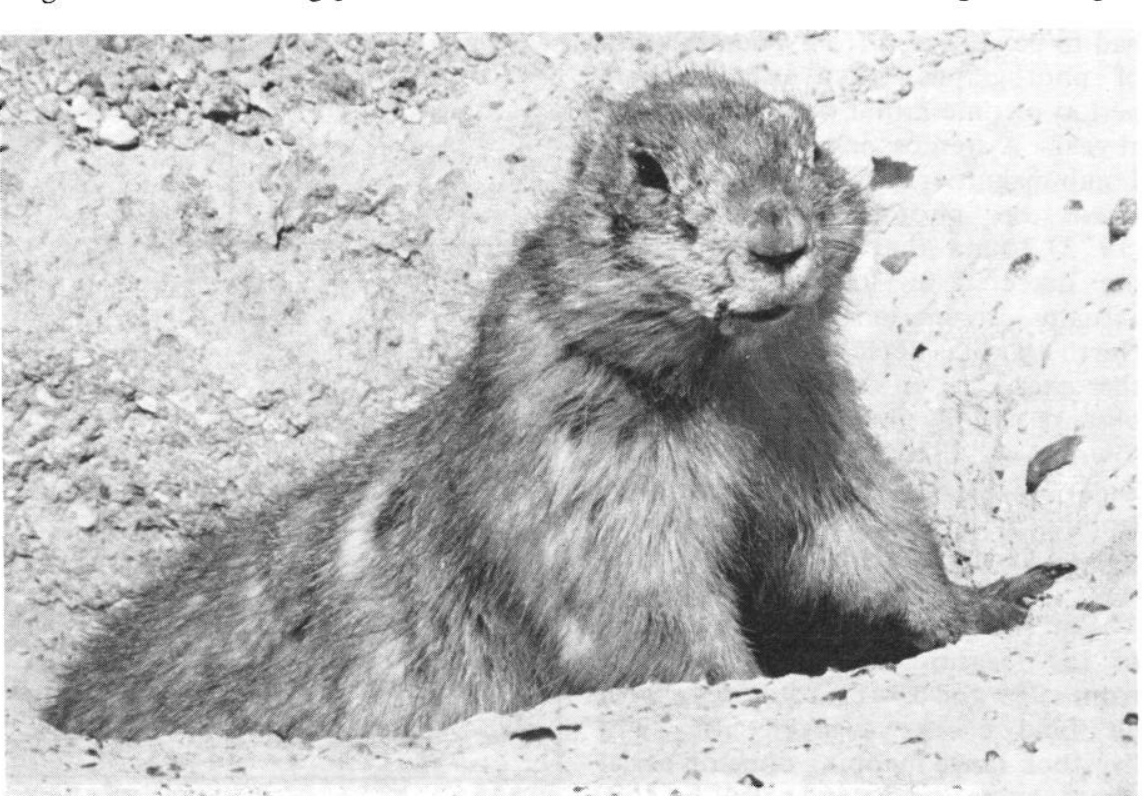

Fig. 1. Black-tailed prairie dog (Cynomys ludovicianus).

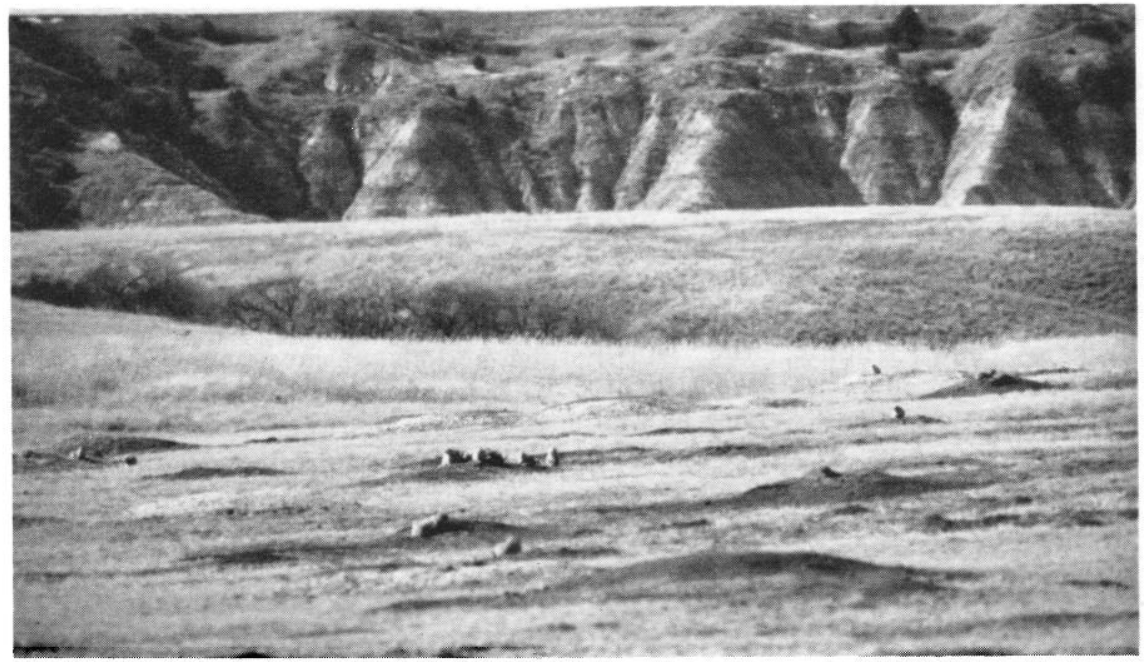

Fig. 2. Typical prairie dog town in North Dakota.
This paper documents the number, size, and distribution of prairie dog towns on a portion of the Little Missouri National Grasslands in North Dakota from 1939 to 1972.

\section{Study Area and Methods}

The administrative boundary of the Medora Ranger District, Custer National Forest, defines the study area in Slope, Golden Valley, and Billings County (Fig. 3). Excluding Theodore Roosevelt National Memorial Park, the study area covers 1,970 square miles and is one of the largest Ranger 
Districts in the U.S. Forest Service. About $40 \%$ is public land on the Little Missouri National Grasslands and 60\% is private and state lands. Much of southwestern North Dakota's sharply eroded badlands, intermingled upland grasslands, and some surrounding rolling grasslands are within the study area. Conspicuous vegetation are mixed prairie of western wheatgrass (Agropyron smithii) and blue grama (Bouteloua gracilis) on uplands, little bluestem (Andropogon scoparius) on hillsides, inland saltgrass (Distichlis stricta) and silver sagebrush (Artemisia cana) on stream terraces, and common juniper (Juniperus communis) and green ash (Fraxinus pennsylvanica) in badlands pockets and along water courses.

Many of the aerial photograph series available covered only portions of the study area or had some photographs of poor quality. As a result, prairie dog town locations and sizes had to be collected from a compilation of photographs taken over a short period of time rather than by individual years. A stereoscope and Bausch and Lomb magnifier improved detection of towns on photographs. Cheatheam (1973) found that aerial photograph use detected $88-94 \%$ of the towns actually present in Texas. In western North Dakota, detcction is reduced by the existence of eroded areas that obscure colony burrows. Prairie dog towns were listed as on private/state land or federal land. Towns overlapping property lines were listed for the ownership having the most acreage.

For the 1939-42 period, a portion of the measurements were obtained from 1939 and 1941 photographs with no field checks available. In 1942 livestock range mapping done on aerial photographs and field checked by U.S. Soil Conservation Service personnel provided data on Slope County.

For the 1957-65 period, a 1957 and a 1965 photograph series were used. No field checks were available or obtained.

For the 1970-72 period, a 1970 and a 1972 photograph series were supplemented with data from other sources. Personnel of the Division of Wildlife Services, Bureau of Sports Fisheries and Wildlife, the North Dakota Game and Fish Department, and the National Park Service as well as other ranchers provided current information. When all information was compiled, field surveys were made to determine prairie dog town locations, sizes, activity, and burrow densities. For small towns, burrow density was calculated for the whole town; for large towns the calculation was based

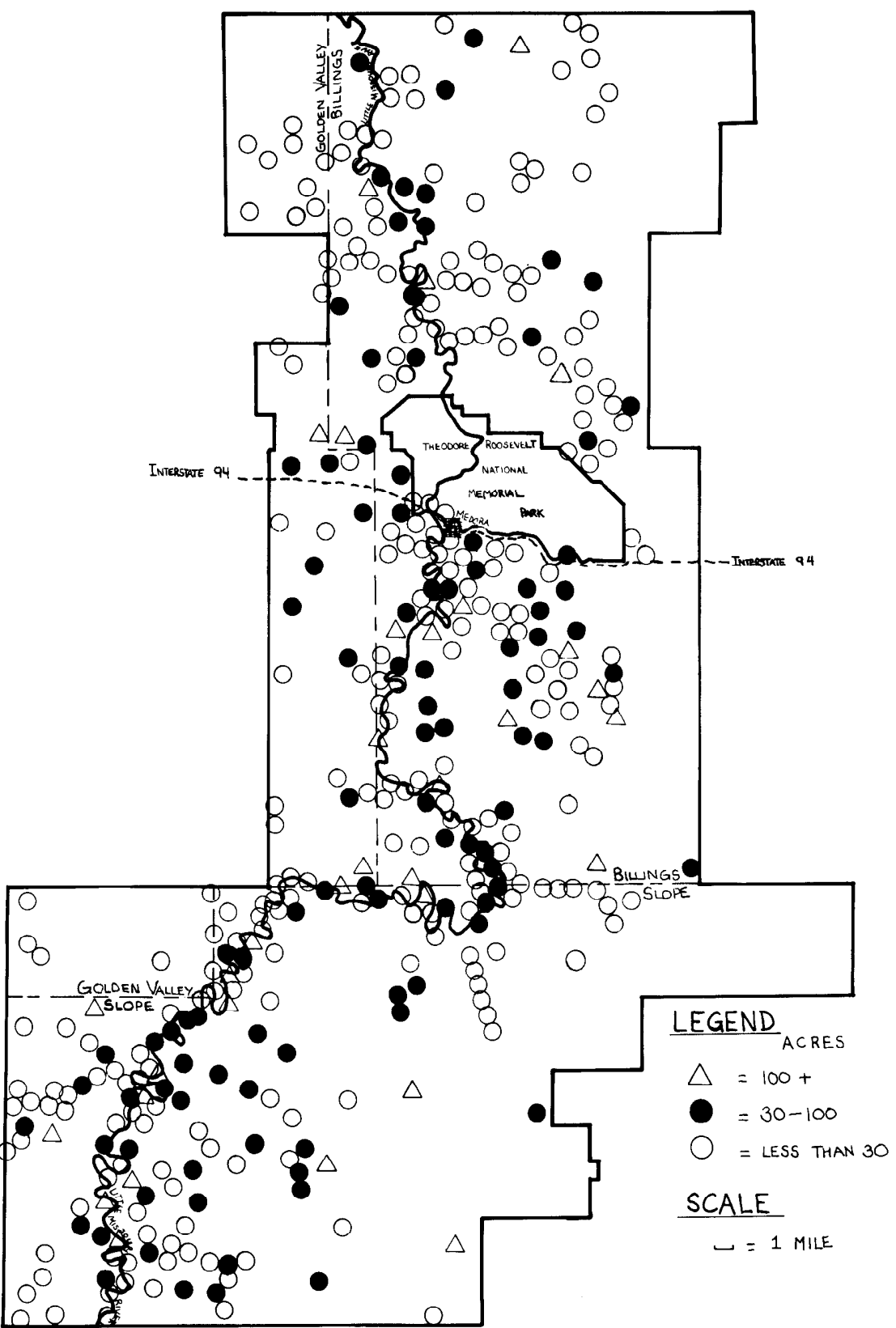

Fig. 3. 1939-42 prairie dog town distribution in the study area.

on the burrow count in 0.25 acre circular plots. In addition, each prairie dog town was examined for signs of ferret activity. Training sessions with ferret specialist Conrad Hillman, in North and South Dakota prairie dog towns, made identification of ferret sign more reliable.

Analysis of variance was used to compare prairie dog town size between the periods of measurement. An unpaired $t$-test was used to test for differences between prairie dog town sizes on private/state land and federal land within each period of measurement (Steel and Torrie, 1960).

\section{Results and Conclusions}

Prairie dog town data are shown in Table 1. The large acreage and num- bers of prairie dog towns in the 1939-42 period could have resulted from the extensive rangeland disturbance which occurred here during and before the drought of the 1930's (Reid, 1954; Bond, 1945; Fichter, 1953). For the 33 year period from 1939 to 1972 the overall reduction in the number of towns was 348 or $89 \%$; and the reduction in total acres was 12,618 or $93 \%$.

The very large towns of early times have been eliminated in this century in the study area. Bailey (1926) mentioned "exceptionally large colonies" in 1913 in the northern fourth of the study area at the mouth of Ash Creek and the head of Magpie Creek. He also reported U.S. Ebner's 1915 observa- 
Table 1. Prairie Dog town number and acreage in the study area from 1939 to 1972.

\begin{tabular}{|c|c|c|c|c|c|c|c|c|c|}
\hline \multirow[b]{2}{*}{ Measurement } & \multicolumn{3}{|c|}{ Federal land } & \multicolumn{3}{|c|}{ Private/state land } & \multicolumn{3}{|c|}{ Study area totals } \\
\hline & No. & Total & $\overline{A v g}$ & No. & Total & $\overline{A v g}$ & No. & Total & Avg \\
\hline \multicolumn{10}{|c|}{ Number and acreage } \\
\hline $\begin{array}{l}1939-42 \\
1957-65 \\
1970-72\end{array}$ & $\begin{array}{r}185 \\
36 \\
23\end{array}$ & $\begin{array}{r}5,981 \\
1,350 \\
512\end{array}$ & $\begin{array}{l}32 \\
38 \\
22\end{array}$ & $\begin{array}{r}207 \\
55 \\
21\end{array}$ & $\begin{array}{r}7,634 \\
1,656 \\
485\end{array}$ & $\begin{array}{l}37 \\
30 \\
23\end{array}$ & $\begin{array}{r}392 \\
91 \\
44\end{array}$ & $\begin{array}{r}13,615 \\
3,006 \\
997\end{array}$ & $\begin{array}{l}35 \\
33 \\
23\end{array}$ \\
\hline $\begin{array}{l}\text { Overall change } \\
1939-72(\%)\end{array}$ & & & & & & & 89 & 93 & 34 \\
\hline
\end{tabular}

tions of towns up to 250 acres scattered along the Little Missouri River in Billings County and a number of colonies up to 160 acres along Beaver Creek in Golden Valley County. Colonies over 100 acres in 1939-42 totaled 32 ; in 1957-65 there were five; and in 1970-72 one remained. Colonies of 30-100 acres in 1939-42 totaled 101; in 1957-65 there were 27 ; and in 1970-72 only 13 such towns were left (Figs. 3 to 5 ). The average town at the beginning of the 33-year study period was 35 acres; in 1972 the average was 23 acres. However, analysis of variance showed that average town size was not significantly different for each of the three periods measured from 1939 to 1972 .

Burrow densities in the 44 towns remaining in 1972 averaged 34 per acre. This is about the same as the 20-40 burrows per acre reported by Bailey (1926).

Analysis of prairie dog town sizes on private/state land compared to federal lands within each of the three periods studied showed no significant difference. Apparently, ownership and any related management or prairie dog control differences have made no difference in town sizes. Prairie dogs have generally been treated over the years as undesirable animals to be eliminated by all owners in this predominantly agricultural-livestock area.

In the 1939-42 period, colonies were well distributed over the study area, especially on the more level lands along the Little Missouri River and its major tributaries. This distribution was reasonably natural based on early reports by Bailey (1926) and the positive correlation between colony location and the medium to fine textured soils found along the drainageways (Hardy, 1945; Reid, 1954).

Since the 1939-42 period, however, two major changes in the distribution of prairie dog towns have occurred. First, colonies have been largely eliminated along the stream courses, probably because these lands are some of the best agricultural and grazing lands in the study area. They are cultivated for hay crops in the summer and used as cattle grazing and wintering areas in the cold months.

Second, in the $1939-42$ period 203 colonies were generally well distributed over Billings County. By 1972,
17 of the 25 colonies remaining in the county were within 3 miles of the boundary of Theodore Roosevelt National Memorial Park. Prairie dogs emigrating from some of the park's many colonies may have established, helped to maintain, or repopulated many of the Billings County colonies found within 3 miles in 1972. Elsewhere in the study area there have been no protected populations to supplement or re-establish towns affected by control activities or shooting, and the number of towns has declined steadily. For National Park lands in the Dakotas, which have had healthy, thriving populations since the 1940's, Lovaas (1973) reported that old town

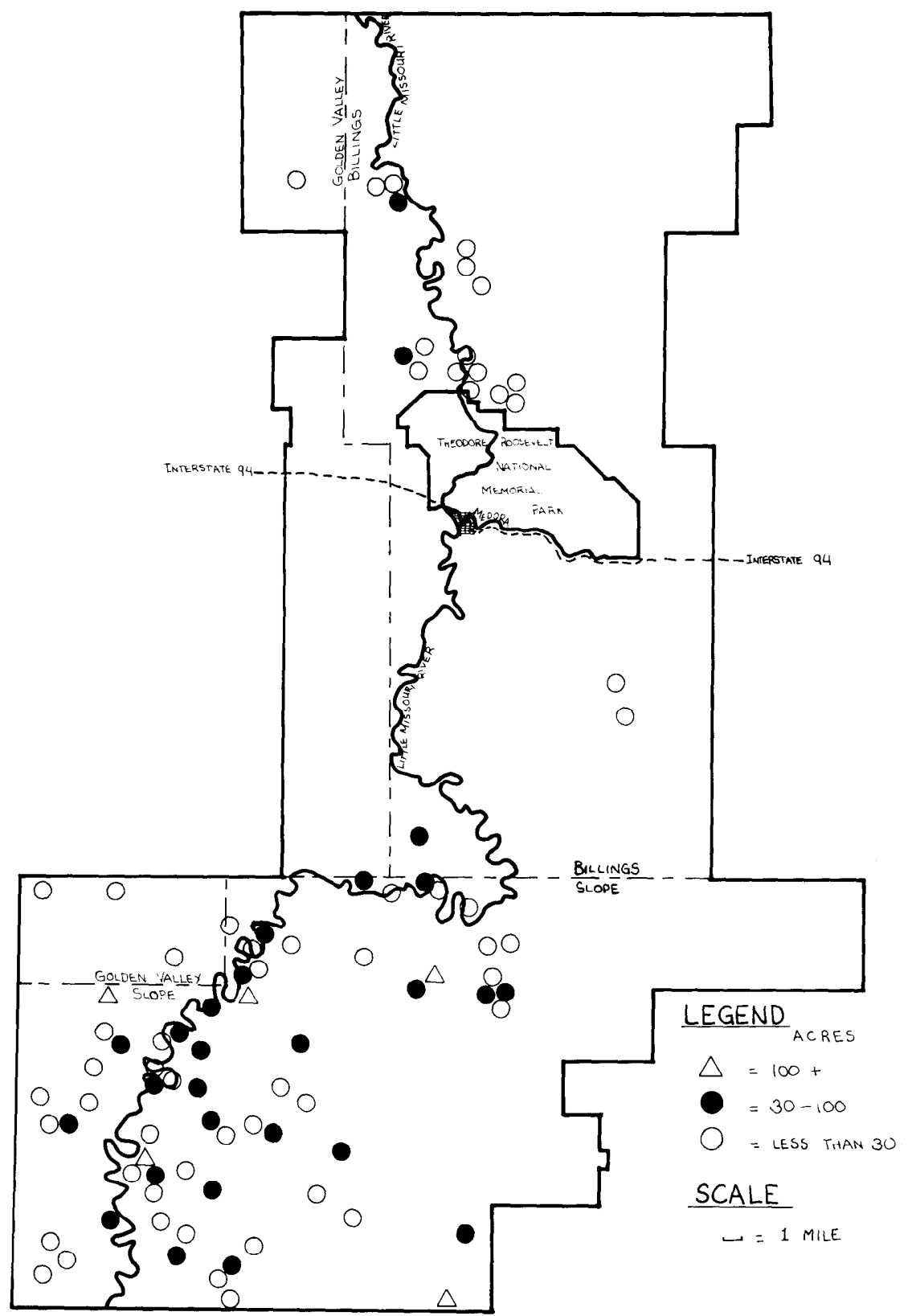

Fig. 4. 1957-65 prairie dog town distribution in the study area. 


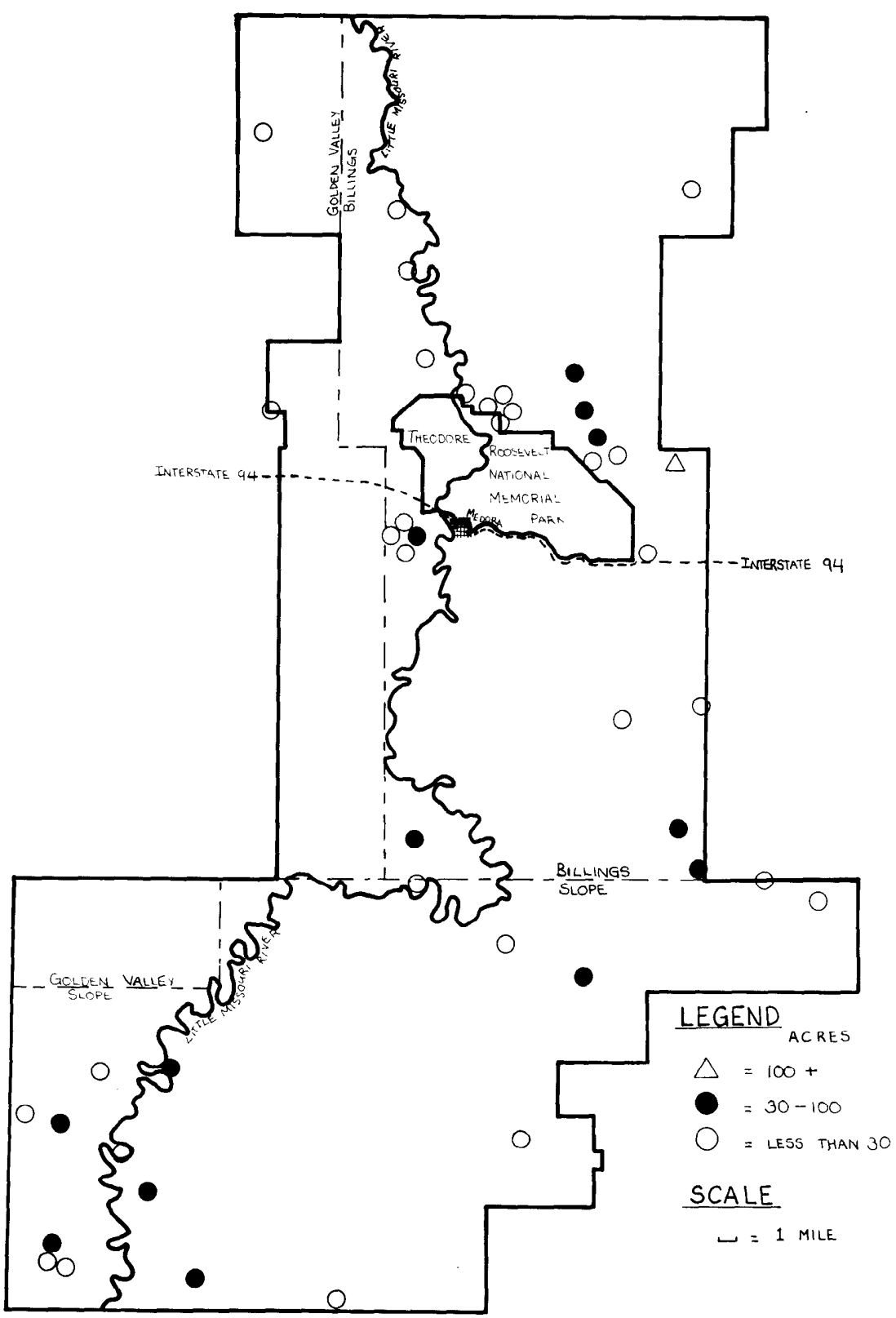

Fig. 5. 1970-72 prairie dog town distribution in the study area.

sites outside the Parks are especially attractive to immigrant prairie dogs.

Prairie dog control in western North Dakota began as early as 1915 by the U.S. Bureau of Biological Survey (Bailey, 1926). Grondahl (1973) reported records of 41,107 acres of prairie dog towns poisoned between 1954 and 1972 by U.S. agents and private landowners in North Dakota, mostly west of the Missouri River. Such treatments and land use changes have apparently been very effective in reducing prairie dog towns in the study area.

No signs or sightings of black-footed ferrets were obtained on any of the 44 towns briefly examined in the field in 1972. However, Grondahl
(1973) reported 25 sightings of ferrets in North Dakota for the 1910-1973 period. Eight of these were in the study area since 1910 and three of these since 1967. Recent reported sightings are frequent, and indicate that ferrets are still resident in the area. Enlightened management for this species habitat has already begun as a result of placing the remaining prairie dog colonies in the perspective of the past 33 years.

\section{Literature Cited}

Bailey, V. 1926. A biological survey of North Dakota. U.S. Dep. Agr., Bureau of Biological Survey. N. Amer. Fauna No. 49, U.S. Government Printing Office, Washington, D.C. 226 p.

Bond, R. M. 1945. Range rodents and plant succession. Trans. 10th N. Amer. Wildl.
Conf. p 229-234.

Cheatheam, L. K. 1973. Censusing prairie dog colonies using aerial photographs. Black-footed Ferret and Prairie Dog Workshop, Sept. 4-6, 1973, Rapid City, S. Dak. South Dakota State Univ., Brookings. 208 p.

Fichter, E. 1953. Control of jackrabbits and prairie dogs on rangelands. J. Range Manage. 6:16-24.

Grondahl, C. R. 1973. Status of the blacktailed prairie dog and the black-footed ferret in North Dakota. Black-footed Ferret and Prairie Dog Workshop, Sept. 4-6, 1973, Rapid City, S. Dak. South Dakota State Univ., Brookings. 208 p.

Hardy, R. 1945. The influence of types of soil upon the local distribution of some mammals in southwestern Utah. Ecol. Monogr. 15:71-108.

Henderson, F. R., and R. J. Little, 1973. Status of the black-footed ferret and black-tailed prairie dog in Kansas. Blackfooted Ferret and Prairie Dog Workshop, Sept. 4-6, 1973, S. Dak. South Dakota State Univ., Brookings. 208 p.

Henderson, F. R., P. F. Springer, and R. Adrian. 1969. The black-footed ferret in South Dakota. South Dakota Dep. of Game, Fish, and Parks, Pierre. 37 p.

Hillman, C. N., and R. L. Linder. 1973. The black-footed ferret. Black-footed Ferret and Prairie Dog Workshop, Sept. 4-6, 1973, Rapid City, S. Dak. South Dakota State Univ., Brookings. 208 p.

Lewis, J. C., and F. Hassien. 1973. Status of prairie dogs and surveys for black-footed ferrets in Oklahoma. Black-footed Ferret and Prairie Dog Workshop, Sept. 4-6, 1973, Rapid City, S. Dak. South Dakota State Univ., Brookings. 208 p.

Lock, R. A. 1973. Status of the blackfooted ferret and black-tailed prairie dog in Nebraska. Black-footed Ferret and Prairie Dog Workshop, Sept. 4-6, 1973, Rapid City, S. Dak. South Dakota State Univ., Brookings, 208 p.

Lovaas, A. L. 1973. Prairie dogs and blackfooted ferrets in the National Parks. Black-footed Ferret and Prairie Dog Workshop, Sept. 4-6, 1973, Rapid City, S. Dak. South Dakota State Univ., Brookings. $208 \mathrm{p}$.

Reid, N. J. 1954. The distribution of the black-tailed prairie dog in the badlands of southwestern North Dakota. MS Thesis. Iowa State Univ., Iowa City. $30 \mathrm{p}$.

Rose, B. J. 1973. History of prairie dogs in South Dakota. Black-footed Ferret and Prairie Dog Workshop, Sept. 4-6, 1973, Rapid City, S. Dak. South Dakota State Univ., Brookings. 208 p.

Scheelhaase, C. G. 1973. Status of the prairie dog in Saskatchewan. Blackfooted Ferret and Prairie Dog Workshop, Sept. 4-6, 1973, Rapid City, S. Dak. South Dakota State Univ., Brookings. $208 \mathrm{p}$.

Sheets, R. G. 1970. Ecology of the blackfooted ferret and the black-tailed prairie dog. MS Thesis. South Dakota State Univ., Brookings. 42 p.

Steel, G. D., and J. H. Torrie. 1960. Principles and procedures of statistics. McGraw-Hill Book Co., New York. 481 p. 